\title{
29. VOLCANIC ROCKS OF NATURALISTE PLATEAU, EASTERN INDIAN OCEAN, SITE 264, DSDP LEG 28
}

\author{
A. B. Ford, U.S. Geological Survey, Menlo Park, California
}

\begin{abstract}
The upper part of a pile of andesitic volcanogenic sediments underlying Upper Cretaceous chalk was sampled on the Naturaliste Plateau at DSDP Site 264. Material recovered from the pile is entirely volcanic and is composed mainly of rock fragments that probably represent coarse clasts in the sequence. Minor conglomerate in which pebbles of volcanic rock are embedded in a highly altered tuffaceous matrix was recovered at two levels. In general, high alteration makes interpretation of original compositions uncertain. The volcanic clasts range widely in composition from rhyolite to probable andesite or basaltic andesite of an apparent calcalkaline andesitic suite unlike any volcanic suite now exposed on nearby parts of southwest Australia. Rhyolitic rocks show apparent ignimbritic textures, suggesting that volcanism in the unknown source volcanic complex was at least in part subaerial. The source terrain must have been nearby, possibly even the plateau which has been only superficially sampled itself. Petrologic and chemical characteristics of the rocks suggest a volcanic island-arc source or perhaps a continental margin volcanic and orogenic belt, now submerged, related to an early stage of development of the eastern Indian Ocean.
\end{abstract}

\section{INTRODUCTION}

Naturaliste Plateau is a submerged, table-like promontory extending about $500 \mathrm{~km}$ westward toward Broken Ridge from Cape Leeuwin in southwestern Australia. The lithologic character of Cretaceous or older materials on the plateau is poorly known; therefore, the origin of the plateau and its setting in the early history of the eastern Indian Ocean is highly conjectural.

The plateau has been penetrated at only two sites of the Deep Sea Drilling Project: Site 258 of Leg 26 on the northern rim, and Site 264 of Leg 28 on the southern edge (Figure 1). At Site 258, drilling terminated in lower Cretaceous glauconitic sand and muddy silt below Al-

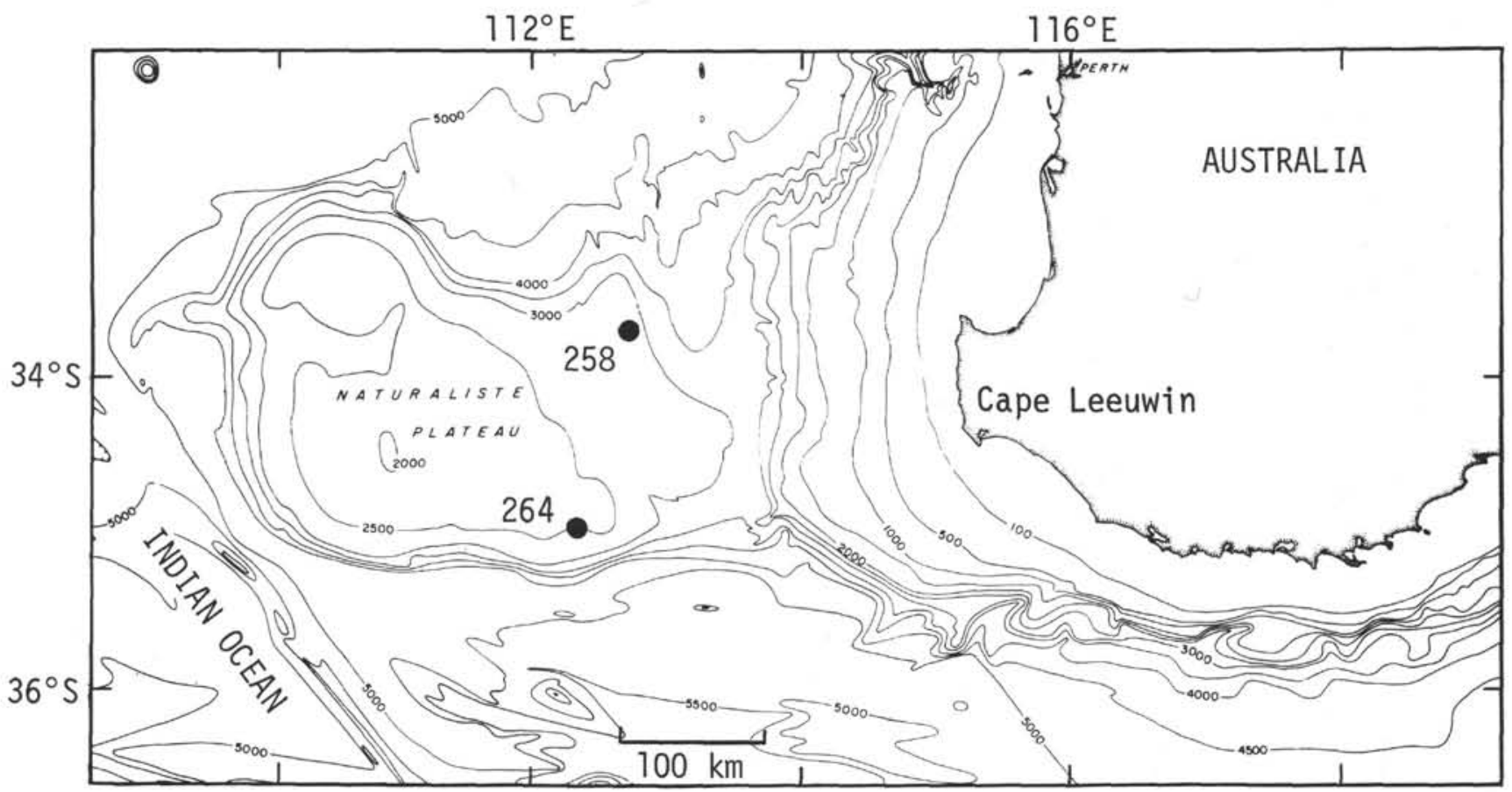

Figure 1. Map of Naturaliste Plateau showing locations of DSDP Sites 258 (Leg 26) and 264 (Leg 28). Bathymetric contours in fathoms. 
bian clay without reaching basement rocks (Davies, Luyendyk, et al., 1974). At Site 264, coring bottomed in highly varied volcanogenic rocks below Cenomanian nannofossil chalk (Site 264 Report, this volume). Compared with overlying calcareous sediments, these volcanic materials are well lithified and form a strong acoustic-basement reflector at about 170 meters below bottom at the drill site.

The plateau has been sampled locally by dredging. Dredge hauls from the steep north scarp by USNS Eltanin Cruise 55 in 1972 yielded manganese slabs, some of which adhered to deeply weathered crystalline continental rocks (Heezen and Tharp, 1973). The character of the dredge samples suggested that the plateau is a subsided part of the Australian continent rather than exceptionally thick oceanic crust as earlier proposed.

One of the purposes of drilling at Site 264 was to investigate the continental or oceanic character of basement terrain from samples obtained in situ. This report describes the petrographic and chemical characteristics of the volcanic materials from the basal unit at the site. The possible tectonic setting of these volcanics in the evolution of this part of the eastern Indian Ocean is briefly discussed. Much remains unknown about this deposit, as it was penetrated only superficially and recovery was very poor. Nonetheless, as it contains lithologic types previously unreported for this region, the materials recovered provide data critical to interpretation of tectonic history of the Naturaliste Plateau and nearby areas.

\section{OCCURRENCE AND AGE}

Volcanic materials of highly varied mineralogy, composition, and texture occur at Site 264 below bottom depth by at least 170.7 meters. Recovery of material was very poor. Broken and abraded rock fragments less than about $8 \mathrm{~cm}$ long were mainly recovered from core catchers to a depth of 215.5 meters at the bottom of the hole. All the materials are altered to some extent, some so strongly that, other than being volcanic, their original lithologic character is obscured.

The contact of the volcanic unit with overlying clayrich nannofossil and foram chalk is probably unconformable. As the actual contact was not observed in any single length of core, some of the comparatively soft intervening chalk, possibly as much as about 6 meters, was probably washed away under high pumping pressures. The downward increase of induration of the calcareous sediments is evidently not related to the underlying igneous materials here described, for the gradual transition from calcareous ooze to chalk occurs nearly 90 meters above the contact, and the lowest chalk recovered is only semilithified and shows no evidence of metamorphic recrystallization. It is unlikely therefore that any of the igneous-rock fragments at the contact represent a sill. Although the contact is probably unconformable, the absence of distinguishable reworked volcanic detritus in the basal chalks suggests that current velocities and local relief were minimal during initial carbonate sedimentation on the surface of the volcanic pile.
The age of the volcanogenic sediment pile and the volcanism is uncertain. The lowest chalk immediately above the deposit contains a range of Cenomanian to Campanian microfossils (see paleontology report for Site 264, this volume). There is some evidence of reworking of the microfossil assemblage by bottom currents. No lower age limit for the volcanic deposit is available and the high degree of alteration of all volcanic materials recovered precludes age determination by radiometric dating. Volcaniclastic sediments that include minor volcanic conglomerate from the Ninetyeast Ridge are dated paleontologically as Paleocene or older (von der Borch, Sclater, et al., 1974). However, in the absence of reported petrochemical data, correlation with the volcanic sediments here described is uncertain.

\section{NATURE OF THE VOLCANIC DEPOSIT}

Petrogenetic interpretation of the volcanic deposit is severely limited by the poor recovery of materials at Site 264. Most recovered material consists of angular to subangular broken fragments of volcanic rock of a single lithology. These fragments could be interpreted as representing flow units within the section. But polymictic rocks with coarsely clastic texture were obtained at two widely separated levels; one in Core 11 near the top of the section, the other in Sample 14, CC. Highly variable coring speed in this unit suggests that the entire drilled "basement" section consists of inhomogeneous material such as hard pebbles, cobbles, and boulders in a soft clayey to sandy matrix similar to that of the polymictic rocks that appear to be volcanic conglomerates (Figure 2). Accordingly, the rock fragments showing a single lithology are considered likely to be pieces of very large clasts from which the matrix has been washed away, and the entire drilled section is inferred to be the upper part of a pile of mainly volcanic sediments including conglomerate, tuff, and possibly breccia. The presence within the section of flow units or even thin sills or dikes cannot be ruled out. Moreover, the mechanism of sediment transport is uncertain; if by water, the materials may have come some, but probably not great, distance from a volcanic center; if by volcanic mudflow, the deposit could represent part of the volcano structure itself.

\section{ANALYTICAL METHODS}

Major-element chemical analyses were made by Paul L.D. Elmore using rapid-rock analytical methods described in U.S. Geological Survey Bulletin 1144-A, supplemented by atomic-absorption analysis. Minorelement abundances were determined by a variety of methods. Th and U were determined by H.T. Millard, P.J. Aruscavage, A. Bartel, and R.A. Zielinski using a delayed-neutron system. S was determined by $\mathrm{L}$. Shapiro using the method of solubility in aqua regia. Au and $\mathrm{Ag}$ were analyzed by L.J. Schwarz by neutronactivation methods using fire assay for the radiochemical separations as described in U.S. Geological Survey Circular 599. Ce, Cr*, Eu, Hf, Nd, Sb, Ta, Th*, and $\mathrm{Yb}^{*}$ were determined by L.J. Schwarz by neutronactivation methods. The reported radioactivation and 

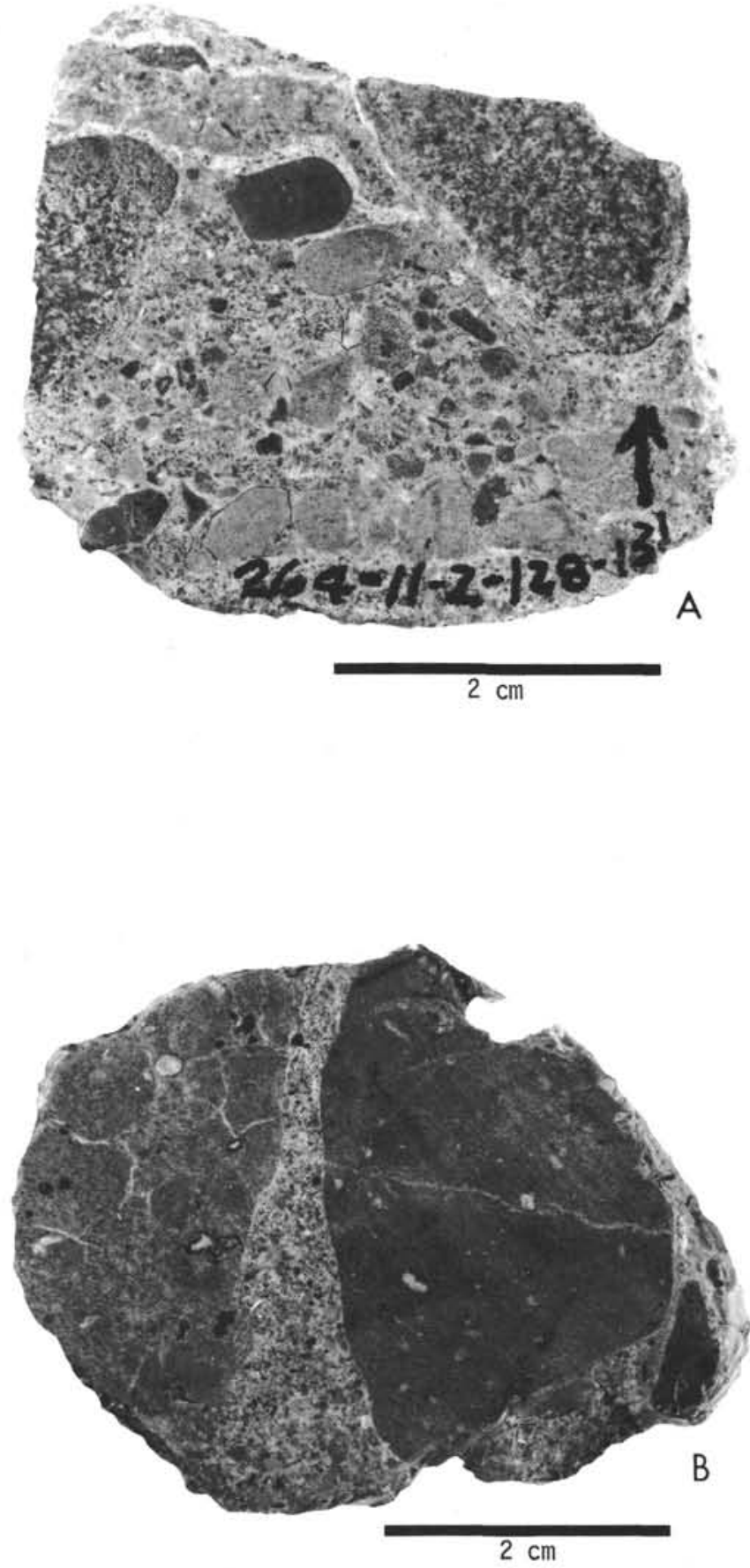

Figure 2. Volcanic conglomerates from Site 264. Subbottom depth 171 meters, near top of volcanic unit (Core 11, Section 2). Largest two pebbles are moderate yellowish-brown (10YRS5/2), highly altered probable andesite. Dark pebbles in upper center and lower left corner are dark yellowish-brown (10YR4/2) altered and devitrified glass with abundant albitized microlites. Matrix in general is moderate yellowish-brown (10YR5/4) with lighter calcite-rich patches. Light veinlets are mostly calcite. Subbottom depth 206 meters (Sample 14, CC). Large pebble on right is pale brown (5YRS/2) highly al- tered probable andesite with a few albitized plagioclase phenocrysts. Large clast on left is grayish olive-green (5GY4/2) altered probable andesite containing a few chlorite- and calcite-filled amygdules. Matrix in center is dusky yellow-green (5GY5/2) and is composed mostly of secondary calcite and altered volcanic granules, sand and silt, and rare fragments of detrital biotite.

radiochemical results are averages using different photopeaks and/or several counting runs; those in two or more significant figures including at least the tenths digit have an overall accuracy of $\pm 10 \%$, and the others are assumed to have an accuracy to $\pm 50 \%$ owing to low counting rate, heavy interference, and/or concentration below detection limit. All other minor elements were determined by R.E. Mays using quantitative spectrographic analysis. Spectrographic results are reported to two significant figures and have an overall accuracy of $\pm 15 \%$ except that they are less accurate near the limits of detection where only one digit is intended. $\mathrm{Cr}, \mathrm{Th}$, and $\mathrm{Yb}$, in different sample splits, were analyzed by both neutron activation (indicated by *) and spectrographic or other methods.

\section{PETROLOGY AND GEOCHEMISTRY}

\section{Alteration Effects}

The igneous rocks from Site 264 are generally highly but variably altered as shown by their common reddish to yellowish-brown color, the abundance of secondary minerals and replacement textures seen in thin section, and such chemical indicators as generally high oxidation index $\left.\left[100 \times \mathrm{Fe}_{2} \mathrm{O}_{3} / 7 \mathrm{Fe}_{2} \mathrm{O}_{3}+\mathrm{FeO}\right)\right]$ and high $\mathrm{H}_{2} \mathrm{O}$ and $\mathrm{CO}_{2}$ content. Most rocks, though highly altered, contain relict minerals and textures that clearly indicate their volcanic parentage. The uncertain nature and magnitude of chemical transfer and oxidation during alteration obscures the nature of the original rock and magma types, as might be inferred directly from chemical analyses.

Alteration doubtless includes the effects of lowtemperature submarine alteration (halmyrolysis) involving seawater interactions. In some rocks, these effects may be superimposed on higher temperature deuteric or metamorphic effects suggested by the presence of greenschist-facies assemblages including albite, epidote, and chlorite. As some rocks apparently were formed above sea level, effects of subaerial weathering may be present.

Submarine alteration results in critical chemical changes that accompany mineralogic alteration. Under conditions of high $\mathrm{CO}_{2}$ activity and free access of seawater, particularly under a cover of carbonate sediments as at Site 264, mafic minerals are attacked faster than plagioclase (Bass et al., 1973). Loss of Ca is chiefly from pyroxenes. In the Site 264 rocks destruction of primary mafic minerals is complete, and apparently at least some released $\mathrm{Ca}$ has combined with $\mathrm{CO}_{2}$ to form the locally abundant carbonate minerals. Plagioclase is variably replaced by albite, forming secondary patchy and normal zoning; in some rocks, plagioclase appears to be little altered. Albitization suggests the gain of $\mathrm{Na}$ 
and $\mathrm{K}$. Chemical changes may include changes in minor-element content, even in the so-called "refractory" elements such as $\mathrm{Zr}, \mathrm{P}$, and $\mathrm{Ti}$, by the destruction of the mafic minerals in which they were mainly contained. Sr and Sc, whose content is highest in the Site 264 rocks with the freshest plagioclase, appear to have been lost during albitization. Owing to the wide compositional range from probable rhyolitic to andesitic or more mafic rock, however, minor-element variation in this suite cannot be uniquely tied to alteration alone. According to Bass et al. (1973), the usual net chemical change produced by submarine alteration, at least in mafic rocks, is an increase in the apparent "alkalinity" of the major elements and a decrease in that of the trace elements.

\section{Volcanic Conglomerate}

The two recovered samples of volcanic conglomerate consist of subangular to subround polymictic volcanic pebbles and granules embedded in a yellowish-brown to yellowish-green, highly altered, clayey to sandy or tuffaceous matrix (Figure 2). Matrix and pebbles are extensively replaced by calcite, to a lesser extent by quartz, chlorite, clays, and iron oxides, and, rarely, by epidote. Calcite and quartz veinlets intricately cut the matrix and, locally, the pebbles. Plagioclase microlites and rare phenocrysts in the pebbles are almost entirely albitized and show only ragged interior patches of calcic plagioclase. Ca was contributed to form the calcite and minor epidote. Alteration masks the original mafic minerals in the pebbles and no identifiable pseudomorphs are present. The pebbles appear, by their color and lack of quartz phenocrysts, to be highly altered andesites. The pebbles are much more highly altered than most of the single-lithology clast fragments described below and this may account for preservation of matrix in the conglomerate.

The high degree of pebble and granule rounding seen in the specimens of Figure 2 suggests transport by water. However, the lithologic character, apparently entirely volcanic, and the extremely poor sorting of the material suggests transport by volcanic mudflow, in which case the rocks could actually represent part of the volcanic complex itself rather than a transported-sediment deposit. A postdepositional age for at least some of the alteration is indicated by the calcite veinlets cutting both matrix and pebbles (Figure 2).

\section{Other Volcanic Rocks}

Most of the rock fragments recovered from Site 264 show a single lithology, and, owing to ambiguity in interpreting their occurrence in the volcanic deposit, are described separately from the apparent conglomeratic rocks. Seven specimens (determined by thin-section study to include the principal variants) were selected for whole-rock chemical analysis. Chemistry of the rocks is highly varied; the range in $\mathrm{SiO}_{2}$, for example, is about $46 \%-72 \%$ (Table 1). Although the freshest appearing samples were selected, alteration has doubtless affected to some degree the bulk chemistry of major and minor elements in all rocks. Attempts to evaluate these changes are probably illusory but seem to show that the rocks have taken on more alkaline characteristics. Owing to their generally fine grain size and extensive alteration, the rocks are classified on the basis of bulk chemistry rather than petrography.

Brief petrographic descriptions follow the analyses of Table 1. Most rocks are porphyritic. The $\mathrm{SiO}_{2}$-rich rocks are devitrified glasses showing well-developed perlitic fracturing and shard-like structures (Figure 3) that closely resemble features of glassy welded tuffs illustrated in Ross and Smith (1961). As the samples analyzed are altered, the powder densities, measured by pycnometer, do not correspond very closely with average densities of the rock types indicated, particularly of the more mafic rocks. The rocks are classified according to Streckeisen (1967), but owing to commonly extensive alteration their nomenclature is somewhat uncertain. Nomenclature problems of rocks in the andesitic field are discussed in detail below.

The possible effects of alteration involving chemical transfer on the calculation of norms is evident-for example, the transfer of alkalis inward and the expulsion of $\mathrm{Ca}$. Such changes, though possibly extensive, cannot be accurately assessed here because no fresh rocks are available for comparison. The generally high content of $\mathrm{H}_{2} \mathrm{O}$ and $\mathrm{CO}_{2}$ is probably not a primary characteristic of these rocks, but the amount that has been added is unknown. Fe oxidation can be a highly significant factor affecting normative mineralogy (Coombs, 1963), particularly in rocks as highly oxidized as these. Oxidation indexes (Table 2 ) for all rocks are high, generally much higher than 40 , which, at least for submarine-weathered basalt, is considered by Cann (1971) to be the limit above which alteration is accompanied by major changes in element abundances. In an attempt to evaluate at least some of the possible changes during alteration, CIPW norms have been calculated from both original analyses and those adjusted by normalizing free of volatiles and recalculating $\mathrm{Fe}_{2} \mathrm{O}_{3}$ in excess of $1.5 \%$ as $\mathrm{FeO}$ (Table 3). The results indicate a large range of uncertainty in original normative compositions. This range of uncertainty, indicated by the lines connecting unadjusted compositions to those adjusted for secondary alterations (Figure 4), chiefly results from $\mathrm{Fe}$ oxidation.

All rocks from Site 264 are Q normative before and after adjusting analyses. The chief effects of reducing $\mathrm{Fe}$ oxidation are a decrease in $\mathrm{Q}$ and an increase in $\mathrm{Hy}$ (Table 3). Although normative $\mathrm{C}$, which indicates a molar excess of $\mathrm{Al}_{2} \mathrm{O}_{3}$ over $\mathrm{Na}_{2} \mathrm{O}+\mathrm{K}_{2} \mathrm{O}+\mathrm{CaO}$, is often suggestive of altered material, the small amounts in these rocks are not uncommonly high for fresh andesites (Chayes, 1969). Adjusted analyses (Table 3) show loss of $\mathrm{C}$ in several rocks; disappearance of $\mathrm{C}$ accompanies the appearance of $\mathrm{Di}$ in the two samples with the least $\mathrm{SiO}_{2}$.

Normalized amounts of $\mathrm{Q}, \mathrm{Or}$, and $\mathrm{Ab}+\mathrm{An}$ plotted in Streckeisen's (1967) ternary classification of volcanic rocks indicate that the Site 264 rocks range widely from rhyolite to andesite (Figure 4). Adjustment for alteration results in migration of plots away from the $\mathrm{Q}$ corner toward the feldspar join. The amounts of migration, however, are insufficient to affect the rock nomenclature. All Ab is arbitrarily allotted to plagioclase; if 
TABLE 1

Major-Element Analyses of Igneous Rocks at Site 264

\begin{tabular}{|c|c|c|c|c|c|c|c|}
\hline & $11, C C^{a}$ & $12, \mathrm{CC}^{\mathrm{b}}$ & $13-1,1^{\mathrm{c}}$ & $13-1,3^{d}$ & $13-1,4^{\mathrm{e}}$ & $13, \mathrm{CC}(1)^{\mathrm{f}}$ & $15, \mathrm{CC}^{\mathrm{g}}$ \\
\hline Plot symbol & A & B & C & D & $E$ & F & G \\
\hline $\mathrm{SiO}_{2}$ & 47.2 & 45.8 & 72.0 & 57.4 & 70.3 & 54.8 & 54.0 \\
\hline $\mathrm{Al}_{2} \mathrm{O}_{3}$ & 17.8 & 17.1 & 12.1 & 12.2 & 12.8 & 15.0 & 16.3 \\
\hline $\mathrm{Fe}_{2} \mathrm{O}_{3}$ & 10.7 & 9.6 & 3.0 & 8.4 & 3.6 & 6.9 & 4.3 \\
\hline $\mathrm{FeO}$ & 0.52 & 0.60 & 0.84 & 2.6 & 1.3 & 3.8 & 4.9 \\
\hline $\mathrm{MgO}$ & 1.6 & 1.3 & 0.56 & 1.8 & 0.76 & 3.1 & 4.7 \\
\hline $\mathrm{CaO}$ & 8.6 & 10.2 & 0.24 & 3.5 & 0.86 & 2.5 & 5.6 \\
\hline $\mathrm{Na}_{2} \mathrm{O}$ & 3.2 & 3.0 & 0.86 & 2.4 & 2.3 & 2.6 & 2.3 \\
\hline $\mathrm{K}_{2} \mathrm{O}$ & 1.0 & 1.1 & 7.7 & 3.8 & 5.2 & 3.0 & 1.9 \\
\hline $\mathrm{H}_{2} \mathrm{O}+$ & 2.3 & 2.1 & 1.4 & 3.0 & 1.4 & 3.9 & 2.8 \\
\hline $\mathrm{H}_{2} \mathrm{O}-$ & 2.0 & 1.6 & 0.46 & 1.3 & 0.45 & 2.1 & 1.3 \\
\hline $\mathrm{TiO}_{2}$ & 2.1 & 2.1 & 0.52 & 1.5 & 0.67 & 1.9 & 1.5 \\
\hline $\mathrm{P}_{2} \mathrm{O}_{5}$ & 0.27 & 0.26 & 0.06 & 1.2 & 0.16 & 0.30 & 0.25 \\
\hline $\mathrm{MnO}$ & 0.14 & 0.12 & 0.04 & 0.17 & 0.09 & 0.09 & 0.11 \\
\hline $\mathrm{CO}_{2}$ & 2.3 & 4.9 & 0.03 & 0.70 & 0.01 & 0.03 & 0.04 \\
\hline Total & 99.7 & 99.8 & 99.8 & 100.0 & 100.1 & 100.0 & 100.0 \\
\hline Rock name & $\begin{array}{c}\text { Andesitic } \\
\text { rock }\end{array}$ & $\begin{array}{c}\text { Andesitic } \\
\text { rock }\end{array}$ & Rhyolite & Rhyodacite & Rhyodacite & Rhyodacite & $\begin{array}{c}\text { Andesitic } \\
\text { rock }\end{array}$ \\
\hline Density & 2.69 & 2.73 & 2.59 & 2.64 & 2.66 & 2.66 & 2.69 \\
\hline Color & $\begin{array}{c}\text { Light } \\
\text { brown } \\
(5 \text { YR5/5) }\end{array}$ & $\begin{array}{c}\text { Light } \\
\text { brown } \\
(5 \text { YR5/5) }\end{array}$ & $\begin{array}{l}\text { Medium } \\
\text { gray } \\
\text { (N5) }\end{array}$ & $\begin{array}{c}\text { Medium } \\
\text { dk gray } \\
\text { (N4) }\end{array}$ & $\begin{array}{c}\text { Medium } \\
\text { dk gray } \\
\text { (N4) }\end{array}$ & $\begin{array}{l}\text { Dk green- } \\
\text { ish-gray } \\
(5 \mathrm{GY} 4 / 1)\end{array}$ & $\begin{array}{c}\text { Medium } \\
\text { gray } \\
\text { (N5) }\end{array}$ \\
\hline
\end{tabular}

Note: Plot symbols are used in Figures 4-8.

${ }^{a}$ Holocrystalline, nonporphyritic rock containing about $50 \%$ little-altered zoned plagioclase, $5 \%$ magnetite, and $45 \%$ alteration products. Plagioclase forms fine-grained laths, locally very weakly aligned, generally between 0.2 and $0.5 \mathrm{~mm}$ long. It is mostly sodic labradorite, $\mathrm{AN}_{51-55}$, of intermediate ordering degree (Figure 7), commonly zoned to more albitic rims of about $\mathrm{AN}_{27}$-38. Alteration products are chiefly translucent hydrous iron oxides in veinlets, films, and patches, with lesser calcite, chlorite, and serpentine-like minerals and traces of epidote, that pervade entire rock. Primary mafic minerals entirely altered. Probably a flow rock but could be hypabyssal.

b Lighology similar to Sample 11, CC.

${ }^{\mathrm{c}}$ Slightly altered, devitrified, vitrophyric glass showing fine lenticular and fragmental structures having shard-like appearance. Perlitic fractures well developed. Rare patches of nondevitrified, pale brown glass. Contains an estimated 5\% phenocrysts, some cumulophyric, of altered albite (An4) to about 2.5 by 1.5 $\mathrm{mm}$ in size. Embayments around phenocryst margins are filled by mesotasis material, which also occurs in small, rounded inclusions, indicating resorption. Alteration products include mainly translucent iron oxides, minor chlorite, and traces of epidote, the epidote in albite phenocrysts. The mode includes several percent of magnetite, probably primary. Coarse layered structure is conspicuous; several large, indistinct masses appear to be collapsed pumice fragments. Structures show evidence of compaction against phenocrysts. Shards show evidence of plasticity and probable welding. The rock is a rhyolitic probable welded tuff.

${ }^{d}$ Devitrified, nearly opaque glass containing abundant lithophysae to about $2 \mathrm{~mm}$ across, consisting of granular quartz and minor opaque oxides. Rare blocky phenocrysts of albitized plagioclase $\left(\mathrm{An}_{5}\right)$ to about 1.5 by $1.0 \mathrm{~mm}$ in size, set in very dark, turbit, microlite-bearing matrix of devitrification products. Cut by veinlets to $0.1 \mathrm{~mm}$ wide of quartz, calcite, chlorite, epidote, and opaque oxides. No evidence of shard structure. Probably a flow rock.

${ }^{\mathrm{e}}$ Altered, devitrified vitrophyre, similar to but much more highly altered and recrystallized than Sample 13-11. Contains about $10 \%$ albitized blocky plagioclase phenocrysts with patchy relict cores of about $\mathrm{An}_{47}$. Contains several percent of lithophysae consisting of rounded masses of granular quartz set in a highly turbid recrystallized matrix of fine quartz and alkali feldspar. Vague, ghost-like, fine lenticular structures resemble shards of Sample 13-11. Local faint concentric structures appear to be relict perlitic fractures. The rock is probably an altered rhyodacitic welded tuff.

${ }^{\mathrm{f}}$ Highly altered fine-grained holocrystalline rock with rare albitized plagioclase phenocrysts to about 3.0 by $1.5 \mathrm{~mm}$. Turbid-appearing groundmass composed of albitized plagioclase laths to about 0.8 by $0.1 \mathrm{~mm}$ in size, quartz, chlorite, iron oxides, and rare epidote. Epidote occurs in albitized phenocrysts also. No recognizable mafic-mineral pseudomorphs, and no evidence of original glass. Probably a flow rock.

$\mathrm{g}_{\text {Lighology similar to Sample } 13, \mathrm{CC}(1) \text {. }}$ 


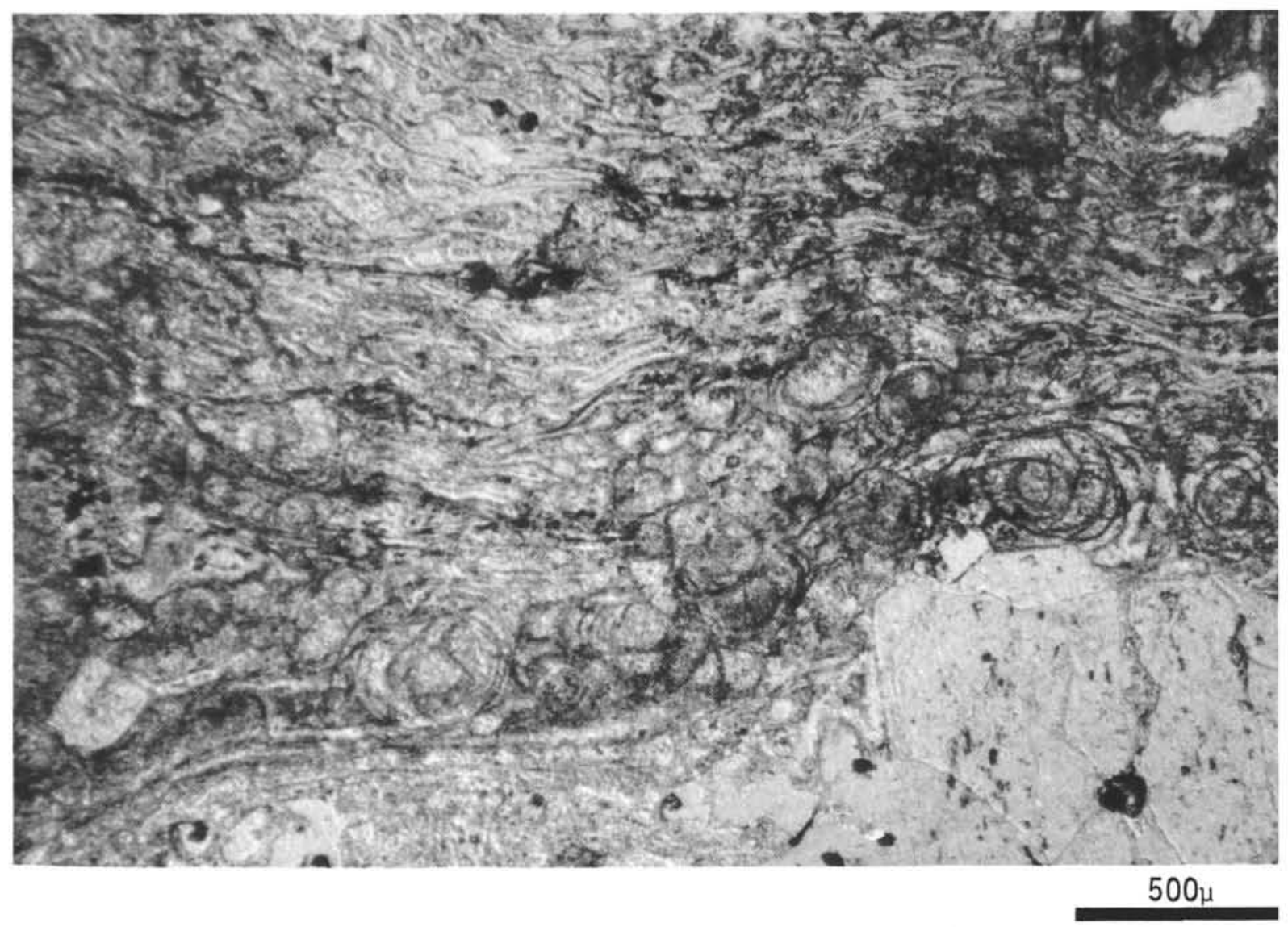

Figure 3. Slightly altered, devitrified, vitrophyric glass of Sample 264-13-1, $1 \mathrm{~cm}$ showing perlitic cracks and fluidal shard textures. Plane light.

TABLE 2

Selected Characteristics of Rocks from Site 264

\begin{tabular}{lccccccr}
\hline & $11, \mathrm{CC}$ & $12, \mathrm{CC}$ & $13-1,1$ & $13-1,3$ & $13-1,4$ & $13, \mathrm{CC}(1)$ & $15, \mathrm{CC}$ \\
\hline $\begin{array}{c}\text { Normative } \\
\text { An percent } \\
\text { (plagioclase) }\end{array}$ & 49.3 & 41.4 & 7.7 & 20.1 & 14.0 & 31.8 & 57.1 \\
$\begin{array}{c}\text { Optical } \\
\text { An percent } \\
\text { (plagioclase) }\end{array}$ & 53 & 53 & 4 & 5 & 47 & - & 40 \\
$\begin{array}{c}\text { Oxidation } \\
\text { index }\end{array}$ & 95.4 & 94.1 & 78.1 & 76.4 & 73.5 & 64.5 & 46.7 \\
$\begin{array}{c}\text { FeO (total) } \\
\text { Mgo }\end{array}$ & 6.3 & 7.1 & 6.3 & 5.6 & 6.0 & 3.2 & 1.9 \\
$\begin{array}{c}\text { Differen- } \\
\text { tiation } \\
\text { index }\end{array}$ & 45.0 & 47.2 & 89.8 & 67.7 & 85.2 & 60.1 & 45.0 \\
$\begin{array}{c}\text { Mafic } \\
\text { index }\end{array}$ & 87.5 & 88.7 & 87.3 & 85.9 & 86.6 & 77.5 & 66.2 \\
\hline
\end{tabular}

partial allotments were made to the orthoclase corner, varying according to the degree of albitization in each sample, several would appear to be considerably more alkalic. Nomenclature would generally not be affected except that the rhyolite ( $c$ in Figure 4 ) might thereby become "alkali rhyolite," probably an inappropriate term as the suite of rocks as a whole seems to have subalkaline characteristics. The differentiation index
(Thornton and Tuttle, 1960) ranges from about 45 for andesitic rocks to near 90 for rhyolite (Table 2).

Nomenclature of the three rocks in the plagioclase corner of the ternary classification (Figure 3 ) is uncertain. Different criteria could class them as either andesitic or basaltic. The unusually low $\mathrm{SiO}_{2}$ content of Samples 11, CC and 12, CC is in the characteristic range for basalt, but in both samples recalculation on a 
TABLE 3

CIPW Weight Norms of Analyzed Rocks from Site 264

\begin{tabular}{|c|c|c|c|c|c|c|c|}
\hline & $11, \mathrm{CC}$ & $12, \mathrm{CC}$ & $13-1,1$ & $13-1,3$ & $13-1,4$ & $13, \mathrm{CC}(1)$ & $15, \mathrm{CC}$ \\
\hline \multicolumn{8}{|c|}{ Norms Calculated From Unadjusted Oxides } \\
\hline Q & 11.2 & 14.7 & 36.6 & 24.3 & 34.7 & 19.5 & 13.8 \\
\hline $\mathrm{C}$ & 1.8 & 4.4 & 2.1 & 2.3 & 2.2 & 3.7 & 0.9 \\
\hline Or & 6.0 & 6.6 & 45.7 & 22.7 & 30.8 & 18.1 & 11.3 \\
\hline $\mathrm{Ab}$ & 27.7 & 25.8 & 7.3 & 20.5 & 19.5 & 22.4 & 19.7 \\
\hline An & 26.9 & 18.2 & 0.61 & 5.1 & 3.1 & 10.4 & 26.2 \\
\hline \multirow{2}{*}{ (Hy) } & 4.0 & 3.2 & 1.4 & 4.5 & 1.9 & 7.8 & 11.8 \\
\hline & - & - & - & - & - & - & 3.2 \\
\hline $\mathrm{Mt}$ & - & - & 1.3 & 4.6 & 2.5 & 7.1 & 6.3 \\
\hline $\mathrm{Hm}$ & 10.9 & 9.7 & 2.0 & 5.3 & 1.8 & 2.0 & - \\
\hline Il & 1.4 & 1.5 & 0.99 & 2.8 & 1.2 & 3.6 & 2.8 \\
\hline $\mathrm{Ru}$ & 1.3 & 1.3 & - & - & - & - & - \\
\hline Ap & 0.65 & 0.62 & 0.14 & 2.8 & 0.38 & 0.72 & 0.60 \\
\hline $\mathrm{CC}$ & 5.3 & 11.3 & 0.06 & 1.6 & 0.02 & 0.07 & 0.09 \\
\hline
\end{tabular}

Norms Recalculated After Adjusting Analyses for Alteration

\begin{tabular}{|c|c|c|c|c|c|c|c|c|}
\hline Q & & 1.5 & 0.67 & 36.2 & 17.2 & 33.5 & 14.6 & 10.9 \\
\hline C & & - & - & 2.1 & 0.68 & 2.2 & 3.9 & 0.91 \\
\hline Or & & 6.4 & 7.1 & 46.5 & 23.8 & 31.4 & 18.9 & 11.7 \\
\hline $\mathrm{Ab}$ & & 29.3 & 28.0 & 7.4 & 21.5 & 19.8 & 23.5 & 20.3 \\
\hline An & & 33.8 & 33.1 & 0.81 & 10.1 & 3.2 & 11.1 & 27.3 \\
\hline & Wo & 4.3 & 8.8 & & & & & \\
\hline Di & En & 1.2 & 2.2 & - & - & - & - & - \\
\hline & Fs & 3.4 & 7.0 & & & & & \\
\hline & En & 3.2 & 1.3 & 1.4 & 4.7 & 1.9 & 8.2 & 12.2 \\
\hline & Fs & 9.3 & 4.1 & 2.0 & 13.5 & 3.7 & 12.5 & 10.5 \\
\hline M & & 2.3 & 2.4 & 2.2 & 2.3 & 2.2 & 2.3 & 2.2 \\
\hline Il & & 4.3 & 4.4 & 1.0 & 3.0 & 1.3 & 3.8 & 2.9 \\
\hline & & 0.69 & 0.68 & 0.14 & 3.0 & 0.38 & 0.76 & 0.62 \\
\hline
\end{tabular}

volatile-free basis raises $\mathrm{SiO}_{2}$ to a value slightly exceeding $50 \%$. Optical composition of plagioclase in Samples 11, CC and 12, CC (Table 2; Figure 5) and normative An in Sample 15, CC (Table 2) exceed Anso, a requirement for basalt in some classifications. However, sodic labradorite is not uncommon in andesitic rocks (Chayes, 1969; Streckeisen, 1967). All three rocks contain abundant $Q$ before norm recalculation from adjusted analyses, and at least minor Q after. Q amounts are within the range reported in andesite, and average normative color index approximates the average value of 21.3 for Cenozoic andesite (Chayes, 1969). Minorelement abundances (Table 4) more closely approximate andesitic than basaltic compositions, particularly $\mathrm{Ni}$ and $\mathrm{Co}$ and the ratio $\mathrm{Ni} / \mathrm{Co}$ as reported by Fleischer (1968). Although uncertainties exist, the three rocks are here classed as andesitic chiefly on the basis of their unusually low MgO (Thompson, 1973) and low color index (Streckeisen, 1967). Streckeisen subdivides the andesitic field at $10 \%$ Or into trachyandesite, which would include samples 12, CC and 15, CC, and true andesite, which would include only Sample 11, CC. The term trachyandesite seems inappropriate for rocks with these low $\mathrm{K}_{2} \mathrm{O} / \mathrm{Na}_{2} \mathrm{O}$ ratios.
Secondary chemical changes possibly include introduction of $\mathrm{K}$ during hydration and devitrification of the siliceous glasses. High $\mathrm{K}_{2} \mathrm{O} / \mathrm{Na}_{2} \mathrm{O}$ ratios of rhyolite and rhyodacite (Table 1) may have resulted from $\mathbf{K}$ metasomatism during alteration of glass (Lipman, 1965).

The subalkaline character of the volcanic suite from Site 264 is displayed in the alkali-silica plot (Figure 6) which shows, for comparison, the alkalic and subalkalic field dividers of Macdonald (1968), based on oceanic tholeiitic and alkalic suites, and of Irvine and Baragar (1971), which includes calcalkaline suites. The fields of Irvine and Baragar are more appropriate for the rocks here described. Adjusting analyses for alteration reduces their apparent "alkalinity" in this diagram.

The suite of volcanic rocks from the Naturaliste Plateau shows characteristics that appear to belong more to the calcalkaline suite than to the tholeiitic suite. Although considerably scattered, most samples plot on an FMA diagram (Figure 7) within the calcalkaline field of Irvine and Baragar (1971, fig. 2). A typical calcalkaline suite, however, should fall in an almost straight band from near midway of the $\mathrm{FeO}-\mathrm{MgO}$ join toward the alkali corner (Green and Ringwood, 1968). 


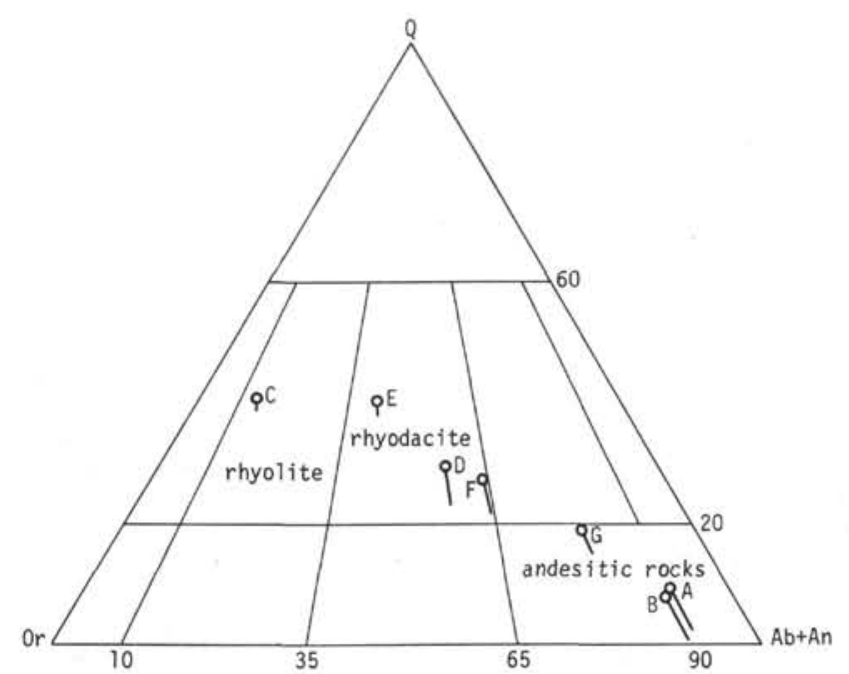

Figure 4. Plots of normative $Q, O r$, and $A b+A n$ in volcanic rocks from Site 264, using the ternary classification of Streckeisen (1967). Compositions of unadjusted analyses shown by open circles. Lines connecting unadjusted compositions to those adjusted for secondary alterations show the probable uncertainty of original rock compositions (see text discussion). Letter symbols indicate sample number in Table 1.

The displacement here toward the $\mathrm{FeO}$ corner suggests $\mathrm{Fe}$ enrichment, a characteristic feature of a tholeiitic series (Jakeś and Gill, 1970). Whether the apparent Fe enrichment is the result of accumulative processes is unknown, but no textural evidence for this is preserved in the altered, Fe-rich rocks. Jakeś and Gill (1970) distinguish tholeiitic and calcalkaline series in island-arc volcanic suites; plots in their fig. 2 of $\mathrm{K}_{2} \mathrm{O}$ against $\mathrm{SiO}_{2}$ for Site 264 rocks are clearly more calcalkaline than tholeiitic. The rocks, however, have unusually high mafic indexes $\left[100 \times\left(\mathrm{FeO}+\mathrm{Fe}_{2} \mathrm{O}_{3}\right) /\left(\mathrm{FeO}+\mathrm{Fe}_{2} \mathrm{O}_{3} 2\right.\right.$ $\mathrm{MgO}$ ), in weight percent] for a calcalkaline series (see Table 2). Plots, not here shown, of the ratio $\mathrm{FeO}$ (total)/MgO against $\mathrm{SiO}_{2}$ in Miyashiro (1974, fig. 1) suggest that the Site 264 rocks belong to an island-arc tholeiitic series.

The possible calcalkaline affinity of this volcanic suite appears to be indicated by relations of total alkalis and $\mathrm{CaO}$ to $\mathrm{SiO}_{2}$ in the diagram of Peacock (1931) shown in Figure 8. Like Figure 6, Figure 8 shows reduction in apparent "alkalinity" when analyses are adjusted for alteration. For unadjusted analyses, the peacock "alkali-lime index"- the $\mathrm{SiO}_{2}$ value at which $\mathrm{Na}_{2} \mathrm{O}+$ $\mathrm{K}_{2} \mathrm{O}=\mathrm{CaO}$ in a suite of related rocks-is about 53 in the alkali-calcic field of Figure 8; this value increases to about 57 in the calcalkaline field, when analyses are recomputed on a volatile-free basis. The sharp increase in $\mathrm{K}_{2} \mathrm{O} / \mathrm{Na}_{2} \mathrm{O}$ ratios to greater than unity in Site 264 rocks more silicic than andesite is a common feature of the calcalkaline series (Green and Ringwood, 1968). Using different criteria, therefore, these rocks might be categorized either as calcalkaline or tholeiitic on the basis of major oxides.
Minor-element concentrations, given in Table 4, show considerable scatter in plots (not here presented) against major oxides. Variation of minor-element concentrations in the suite is a consequence of major differences in original rock types and of secondary alterations, but the contribution of either factor alone cannot be assessed in the absence of fresh material. As might be expected, high $\mathrm{U}$ and $\mathrm{Zr}$ are associated with high $\mathrm{SiO}_{2}$ whereas high $\mathrm{Ni}$ and $\mathrm{Cu}$ correlate with low $\mathrm{SiO}_{2}$. Ni and $\mathrm{Cu}$ do not seem closely related to $\mathrm{MgO}$. High Sc and $\mathrm{Sr}$ are apparently related to abundance of little-altered plagioclase. Except for high $\mathrm{Cr}$ in Samples $11, \mathrm{CC}$ and $12, \mathrm{CC}$, the minor-element concentrations do not differ greatly from those of calcalkaline volcanic suites tabulated by Taylor (1969).

Plagioclase compositions were determined optically by the universal-stage method of Uruno (1963), in which Kohler's angles $\mathrm{X} \wedge \mathrm{X}$ and $\mathrm{Y} \wedge \mathrm{Y}$ are measured across (010) on stereogram plots of optical directions of adjoining albite twins. After determining compositions and average ordering degree from several such measurements (Figure 5), additional determinations were made by the faster method of rotating the crystal axis $a$ parallel to the microscope axis and using, or interpolating between, the appropriate high- or low-T extinction curves of Tobi (1963). Optical plagioclase compositions listed in Table 2 are average determinations of the major parts of crystals and do not include zoned rims or groundmass plagioclases, which are usually much more sodic. They therefore do not correspond closely with calculated normative compositions.

\section{INTERPRETATION}

\section{Character of the Basement}

The Naturaliste Plateau is considered by Johnstone et al. (1973) to be a submerged part of the continental Leeuwin-Naturaliste Block, about 670 m.y. old, of southwestern Australia, and is separated from the Archean Yilgarn Block to the east by the Darling fault. Continental-type crystalline rocks dredged from the north scarp of the plateau (Heezen and Tharp, 1973) support the suggestion of a continental foundation.

The plateau also appears to be a physiographic extension of Broken Ridge in the Indian Ocean to the west and conceivably could share similarities of basement structure with that feature. The nature of Broken Ridge is controversial. Whereas Dietz and Holden (1971) consider it to be of simatic origin, McKenzie and Sclater (1971) suggest, on the basis of seismic characteristics, that it is a continental fragment once joined to Kerguelen Plateau at an edge of some part of Gondwanaland, postulating that Broken Ridge separated from Kerguelen Plateau, along with Australia from Antarctica, by Eocene spreading from the Southeast Indian Ridge. Recent studies, however, indicate that Kerguelen is a simple oceanic island consisting mainly of tholeiitic to alkalic basalt and trachyte with no evidence of any continental materials (Watkins et al., 1974). If Broken Ridge is indeed related to Kerguelen, it therefore is more likely to be oceanic than continental in character. 


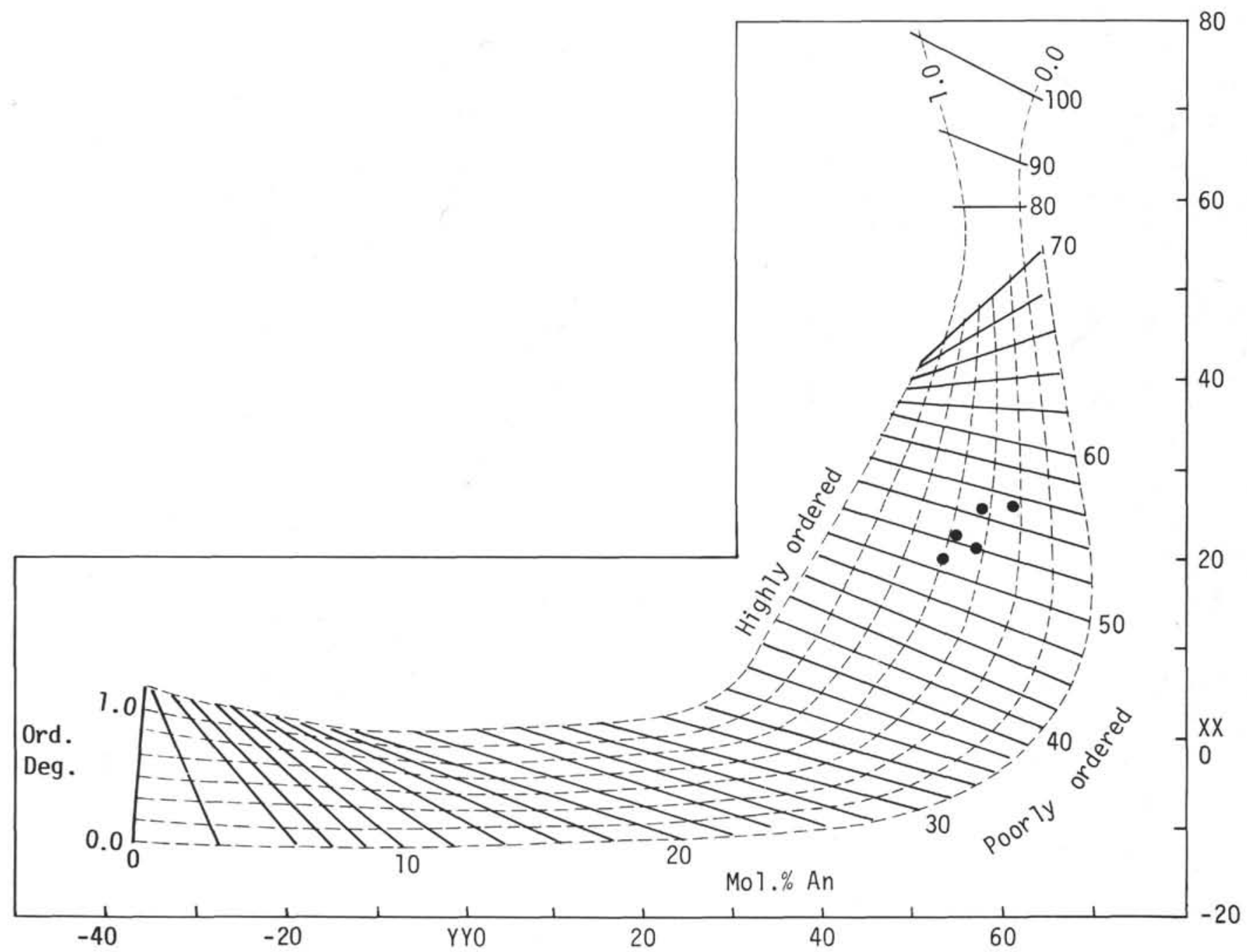

Figure 5. Optical plots of plagiocalse in Samples 11, CC and 12, CC showing composition and intermediate ordering degree in diagram of Uruno (1963). Vertical axis, $X \wedge X$ Kohler angle; horizontal axis, $Y \wedge Y$ Kohler angle. An content shown on solid diagonal lines.

The term "basement" is relative. The volcanic materials described can be considered to make up the basement of the section of Cenozoic carbonate sediments on this part of Naturaliste Plateau and they form the acoustic basement in seismic profiler records. Direct examination of these basement rocks indicates that they have chemical and petrographic characteristics much more like continental or island-arc volcanic rocks than oceanic rocks. For example, rhyolites of oceanic regions, unlike the Site 264 rhyolitic rocks, commonly have pantelleritic compositions (McBirney, 1969). Drilling at Site 264, however, penetrated the volcanic deposit only superficially without reaching the basement on which it in turn rests. The sampled section contains no apparent debris reworked from this basement, the nature of which can only be inferred as probably continental on the basis of the nature of the overlying volcanic rocks. Although such an inference might be invalid if the volcanoclastic debris came from a distant volcanic source, apparent lack of mixing with nonvolcanic detritus suggests a local source. Moreover, the interpretation of a continental, including island-arc, foundation is supported if this deposit consists largely of mudflow breccias and tuffs representing part of the volcano structure itself as appears possible from the available evidence.

\section{Setting in Eastern Indian Ocean and the Question of Source Terrain}

The recovery of Cretaceous or older subalkaline andesitic volcanic rocks on Naturaliste Plateau is significant because such rocks have not been known in the area. Consisting of the basalt-andesite-dacite-rhyolite series, the andesitic suite characterizes volcanism in island arc and continental margin orogenic zones (Green and Ringwood, 1968) that are now commonly postulated to be related to converging plate margins (Mitchell and Reading, 1971). If these generalizations 
TABLE 4

Minor Elements in Site 264 Volcanic Rocks

\begin{tabular}{|c|c|c|c|c|c|c|c|}
\hline & $11, \mathrm{CC}$ & $12, \mathrm{CC}$ & $13-1,1$ & $13-1,3$ & $13-1,4$ & 13, CC (1) & $15, \mathrm{CC}$ \\
\hline $\mathrm{Ag}$ & $0.29,0.32$ & $<0.01$ & $0.20,0.22$ & 0.17 & 0.16 & $0.03,0.03$ & 0.13 \\
\hline $\mathrm{Au}^{\mathrm{a}}$ & $0.3, \quad 0.3$ & 0.6 & $0.3,0.6$ & 0.4 & 0.8 & $0.3, \quad 0.2$ & 0.3 \\
\hline B & $\mathrm{N} 20$ & N20 & N20 & N20 & N20 & N20 & N20 \\
\hline $\mathrm{Ba}$ & 70 & 70 & 900 & 900 & 1400 & 320 & 280 \\
\hline $\mathrm{Ce}$ & 27.0 & 21.5 & 134.4 & 84.8 & 125.8 & 60.4 & 38.2 \\
\hline Co & 32 & 32 & 5 & 18 & 8 & 28 & 19 \\
\hline $\mathrm{Cr}_{\mathrm{b}}$ & 300 & 340 & 8 & 30 & 20 & 55 & 120 \\
\hline $\mathrm{Cr}^{\mathrm{b}}$ & 243 & 251 & 14 & 26 & 15 & 34 & 75 \\
\hline $\mathrm{Cu}$ & 80 & 80 & 22 & 11 & 13 & 13 & 24 \\
\hline $\mathrm{Eu}$ & 1.6 & 1.6 & 2.5 & 3.6 & 2.7 & 1.7 & 1.4 \\
\hline $\mathrm{Hf}$ & 3.8 & 3.6 & 12.6 & 7.0 & 14.0 & 5.8 & 3.8 \\
\hline $\mathrm{La}$ & $\mathrm{N} 40$ & $\mathrm{~N} 40$ & 120 & $\mathrm{~N} 40$ & 100 & $\mathrm{~N} 40$ & N40 \\
\hline $\mathrm{Nd}$ & 22 & 14 & 63 & 51 & 59 & 34 & 22 \\
\hline $\mathrm{Ni}$ & 42 & 36 & N2 & N2 & N2 & 11 & 14 \\
\hline $\mathrm{Pb}$ & $\mathrm{N} 20$ & $\mathrm{~N} 20$ & $\mathrm{~N} 20$ & N20 & 40 & $\mathrm{~N} 20$ & $\mathrm{~N} 20$ \\
\hline $\mathrm{S}$ & 0 & 0 & 0 & 300 & 100 & 100 & 500 \\
\hline $\mathrm{Sb}$ & 1.1 & 0.5 & 0.2 & 0.4 & 0.2 & 0.3 & 0.2 \\
\hline $\mathrm{Sc}$ & 44 & 44 & 4 & 16 & 6 & 24 & 32 \\
\hline $\mathrm{Sr}$ & 300 & 300 & 34 & 120 & 120 & 120 & 240 \\
\hline Ta & 0.4 & 0.6 & 1.0 & 0.6 & 1.0 & 0.5 & 0.4 \\
\hline Th & NA & NA & 10.9 & 3.03 & NA & NA & 4.83 \\
\hline $\mathrm{Th}^{\mathrm{b}}$ & 1 & 1 & 10.8 & 4.6 & 12.2 & 6.8 & 3.6 \\
\hline $\mathrm{U}$ & 0.33 & 0.29 & 0.78 & 0.74 & NA & NA & 0.54 \\
\hline V & 200 & 180 & 22 & 110 & 20 & 180 & 180 \\
\hline Y & 50 & 50 & 60 & 110 & 60 & 60 & 50 \\
\hline $\mathrm{Yb}$ & 2 & 2 & 3 & 6 & 3 & 3 & 2 \\
\hline $\mathrm{Yb}^{\mathrm{b}}$ & 3.3 & 3.3 & 6.4 & 1.8 & 5.8 & 3.9 & 3.0 \\
\hline $\mathrm{Zr}$ & 140 & 120 & 300 & 200 & 300 & 170 & 130 \\
\hline
\end{tabular}

Note: See text for analysts and methods. $\mathrm{N}=$ not detected at value shown; $\mathrm{NA}=$ not analyzed.

${ }^{\mathrm{a}}$ All values in ppm except for $\mathrm{Au}$, which is given in $\mathrm{ppb}$.

${ }^{\mathrm{b}}$ Analysis by neutron activation.

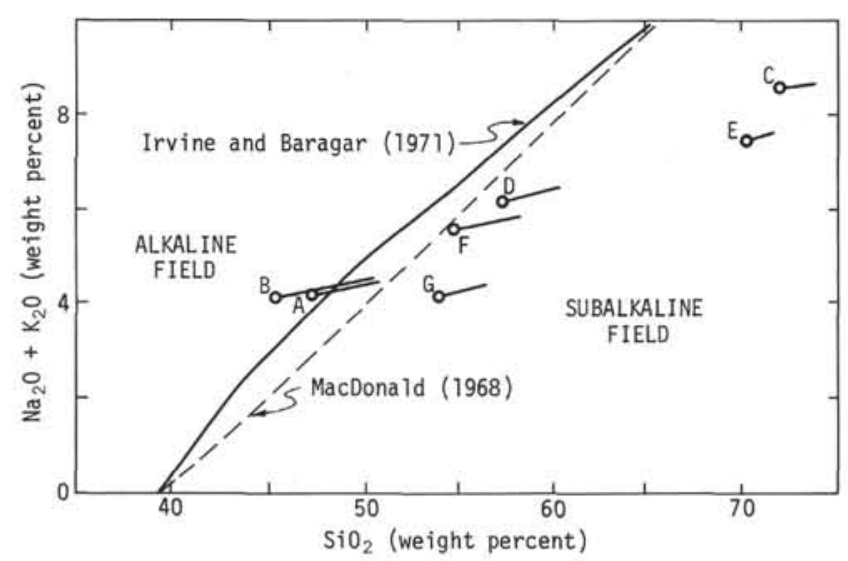

Figure 6. Total alkalis $\left(\mathrm{Na}_{2} \mathrm{O}\right.$ and $\left.\mathrm{K}_{2} \mathrm{O}\right)$ - silica plot, in weight percent, of volcanic rocks of Site 264. For explanation of plot symbols, see Figure 4.

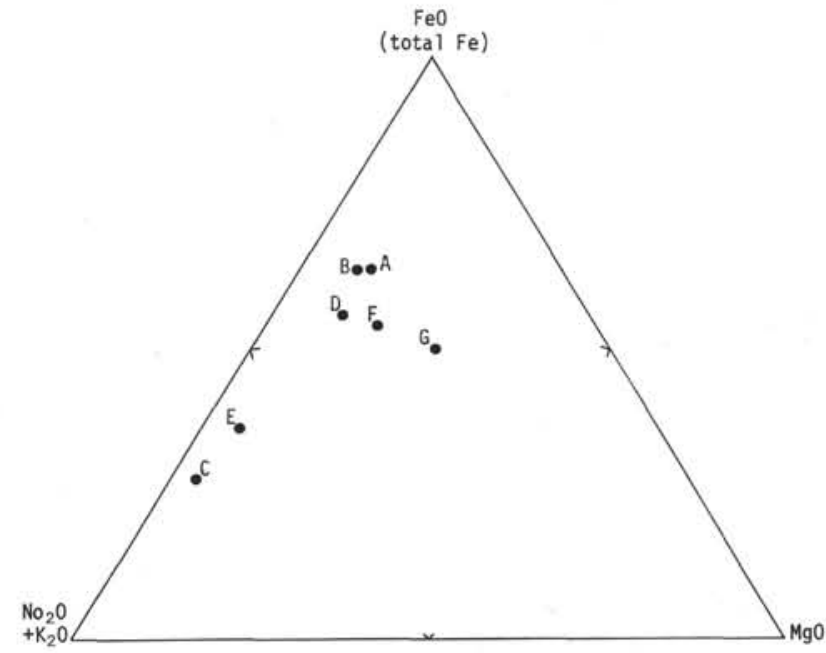

Figure 7. FMA diagram, in weight percent, showing plots of volcanic rocks at Site 264. For sample represented by letter, see Table 1. 


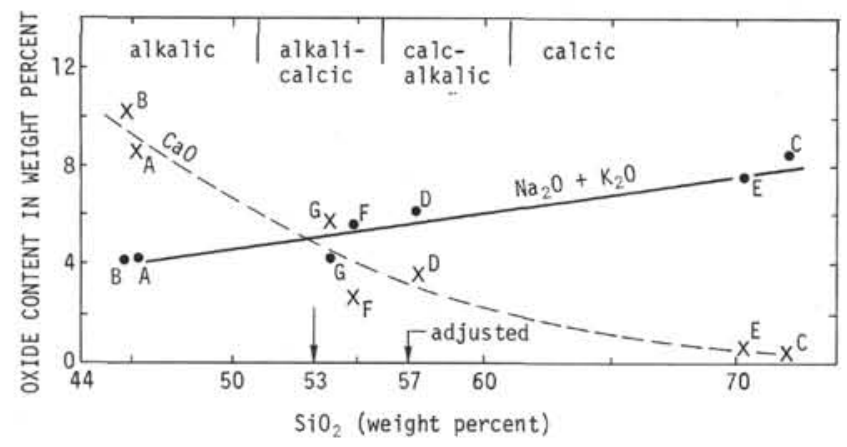

Figure 8. Variations of weight percent $\mathrm{CaO}$ and alkalis related to $\mathrm{SiO}_{2}$ in the volcanic rock suite from Site 264, indicating alkali-lime index (see text) of about 53. A parallel but different set of curves, not shown, indicates an index of about 57 for oxide amounts normalized volatile-free. Subdivisions of alkalic to calcic fields are those of Peacock (1931). For sample represented by letter symbol, see Table 1.

are valid and if the rocks recovered from Site 264 are assumed to represent part of the actual volcano complex, then this area might be part of an old island-arc system related to an early stage of eastern Indian Ocean development. If the volcanic debris consists of mostly transported material, then this area at the time of accumulation probably lay near an island-arc or continental andesitic complex.

If the source must be sought elsewhere, the calcalkaline andesitic fingerprint should identify the terrain. The nearest onland volcanic rocks of possibly similar age belong to the Bunbury Basalt, dated originally by Edwards (1938) as Tertiary but now believed to be Neocomian (Johnstone et al., 1973). The restricted range of tholeiitic basalt compositions of the Bunbury (Edwards, 1938) rules it out as a potential source, at least for the section sampled at Site 264. Recent offshore drilling at the northern end of Perth Basin penetrated a thick volcanic pile consisting chiefly of rocks of apparent alkalic compositions (E. M. Kemp, written communication, 1973); its age is unknown and compositions of the rocks are probably unlike those at Site 264.

Possible source terrains, even if originally near, might be distant if the McKenzie and Sclater (1971) concept of Eocene fragmentation of this part of Gondwanaland is valid. All central and eastern Indian Ocean coastlines, according to Fairbridge (1965), are of the "Atlantic" or passive type except for the arc-trench system adjoining Southeast Asia. Reconstructions of these parts of Gondwanaland are highly varied (Figure 9), except for the generally accepted, simple meridional closure of the southeast Indian Ocean normal to its axial ridge. The southeast Indian Ocean closure juxtaposes the southwest corner of Australia, and in most reconstructions presumably the Naturaliste Plateau, with western Wilkes Land, Antarctica, an area near known centers of Tertiary alkalic volcanism (Watkins et al., 1974) but where Cretaceous or older calcalkaline volcanism is not known. Southwest Australia and presumably the Naturaliste Plateau in the Dietz and Holden (1971)

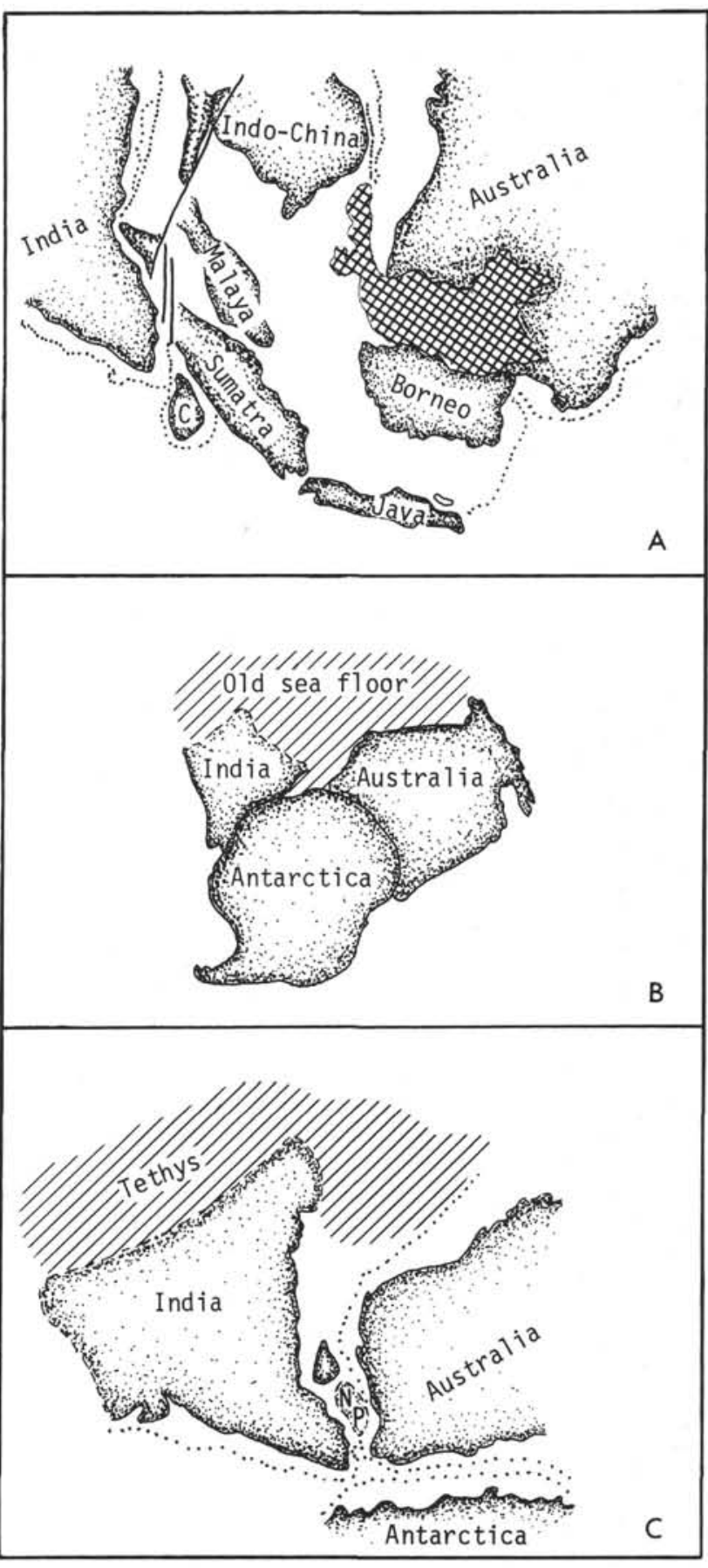

Figure 9. Diagrammatic sketches showing suggested late Paleozoic reconstructions. Ridd (1971); Dietz and Holden (1971); Veevers et al. (1971). Dotted lines in a and c 1000-meter isobath. $C=$ Ceylon; NP=Naturaliste Plateau Cross-hatched area in a, overlap of Southeast Asia with Australia.

reconstruction would lie between Antarctica and a region of old sea floor (Figure 9b), but the recent discovery of the young age of Wharton Basin (von der Borch, Sclater, et al., 1974) argues against this possibility. Volcanic sources that would support Veevers et al. (1971) in their placement of the Naturaliste Plateau between Ceylon, India, and Western Australia (Figure 
9c) are not known. Moreover, this placement seems unlikely if the Site 264 volcanic rocks are relatable to an andesitic island-arc belt along a convergent plate boundary.

The nearest known region of island-arc andesitic volcanism is Southeast Asia. The Site 264 volcanic materials might support Ridd's (1971) fitting of southwestern Australia near Borneo (Figure 9a). His inclusion of Southeast Asia as part of Gondwanaland, based on stratigraphic similarities and the fragmentary presence of a Glossopteris flora, is strongly questioned by Griffiths and Burrett (1973) on the basis of major differences in fauna and paleoclimate. The geometric fit of Southeast Asia to Western Australia, moreover, is extremely poor and it seems fortuitous that all of the orogenic volcanic arc fragmented away, leaving no trace on Australia or India. And, if the Naturaliste Plateau were part of a volcanic arc adjoining southwest Australia, a record of this should be seen in Australian rocks. The absence of any such known record suggests a transform fault separating these two regions, but how such a conjectural fault relates to nearby oceanic fracture zones is unknown. The results of drilling at Site 264 suggest that early chapters in eastern Indian Ocean history include a phase of convergent plate activity in a region heretofore considered only as extensional by simple rifting of Mesozoic Gondwanaland. However, the early record is exceedingly fragmentary. How this possible convergent plate activity, which is suggested by the andesitic compositions, fits into the regional tectonic history is not now known.

\section{ACKNOWLEDGMENTS}

I am indebted to all fellow shipboard members of Leg 28 of D/V Glomar Challenger, including ship's crew, drilling crew, DSDP technical staff, and scientific staff, and, for shore-based studies, to analysts of the U.S. Geological Survey. In particular, I am indebted to P.J. Barrett, who helped on shipboard studies of the Site 264 volcanic rocks, and to R.L. Christiansen, who made valuable comments on the manuscript.

\section{REFERENCES}

Bass, M.N., Moberly, R., Rhodes, J.M., Shih, Chi-yu, and Church, S.E., 1973. Volcanic rocks cored in the central Pacific, Leg 17, Deep Sea Drilling Project. In Winterer, E.L., Ewing, J.I., et al., Initial Reports of the Deep Sea Drilling Project, Volume 17: Washington (U.S. Government Printing Office), p. 429-503.

Cann, J.R., 1971. Major element variations in ocean-floor basalts: Roy. Soc. London Phil. Trans., ser. A., v. 268, p. 495-505.

Chayes, F., 1969. The chemical composition of Cenozoic andesite. In McBirney, A.R., (Ed.), Proc. Andesite Conf.: Oregon Dept. Geol. Min. Indus. Bull. 65, p. 1-11.

Coombs, D.S., 1963. Trends and affinities of basaltic magmas and pyroxenes as illustrated on the diopside-olivine-silica diagram: Mineral. Soc. Am. Spec. Paper 1, p. 227-250.

Davies, T.A., Luyendyk, B., et al., 1974. Initial Reports of the Deep Sea Drilling Project, Volume 26: Washington (U.S. Government Printing Office).

Dietz, R.S. and Holden, J.C., 1971. Pre-Mesozoic oceanic crust in the eastern Indian Ocean (Wharton Basin)?: Nature, v. 229, p. 309-312.
Edwards, A.B., 1938, Tertiary tholeiitic magma in western Australia: J. Roy. Soc. Western Australia, v. 24, p. 1-12.

Fairbridge, R. W., 1965. The Indian Ocean and the status of Gondwanaland. In Sears, M. (Ed.), Progress in oceanography, v. 3: New York (Pergamon Press), p. 83136.

Fleischer, M., 1968. Variation of the ratio $\mathrm{Ni} / \mathrm{Co}$ in igneous rock series: J. Washington Acad. Sci., v. 58, p. 108-117.

Green, T.H. and Ringwood, A.E., 1968. Genesis of the calcalkaline igneous rock suite: Contrib. Mineral. Petrol., v. 18 , p. $105-162$.

Griffiths, J. and Burrett, C., 1973. Were South-east Asia and Indonesia parts of Gondwanaland?: Nature Phys. Sci., v. 245 , p. $92-93$.

Heezen, B.C. and Tharp, M., 1973. USNS Eltanin Cruise 55: Antarctic J. U.S., v. 8, p. 137-141.

Irvine, T.N. and Baragar, W.R.A., 1971. A guide to the chemical classification of the common volcanic rocks: Canadian J. Earth Sci., v. 8, p. 523-548.

Jakes, P. and Gill, J., 1970. Rare earth elements and the island arc tholeiitic series: Earth Planet. Sci. Lett., v. 9, p. 17-28.

Johnstone, M.H., Lowry, d.C., and Quilty, P.G., 1973. The geology of southwestern Australia-a review: J. Roy. Soc. Western Australia, v. 56, p. 5-15.

Lipman, P.W., 1965. Chemical comparison of glassy and crystalline volcanic rocks: U.S. Geol. Surv. Bull. 1201-D.

Macdonald, G.A., 1968. Composition and origin of Hawaiian lavas: Geol. Soc. Am. Mem. 116, p. 477-522.

McBirney, A.R., 1969. Andesitic and rhyolitic volcanism of orogenic belts. In Hart, P.J. (Ed.), The earth's crust and upper mantle: Am. Geophys. Union, Geophys. Monogr. 13, Washington, p. 501-507.

McKenzie, D. and Sclater, J.G., 1971. The evolution of the indian Ocean since the Late Cretaceous: Roy. Astron. Soc. Geophys. J., v. 25, p. 437-528.

Mitchell, A.H. and Reading, H.G., 1971. Evolution of island arcs: J. Geol., v. 79, p. 253-284.

Miyashiro, A., 1974. Volcanic rock series in island arcs and active continental margins: Am. J. Sci., v. 274, p. 321-355.

Peacock, M.A., 1931. Classification of igneous rock series: J. Geol. v. 39 , p. $54-67$.

Ridd, M.F., 1971. Southeast Asia as a part of Gondwanaland: Nature, v. 234, p. 531-533.

Ross, C.S. and Smith, R.L., 1961. Ash-flow tuffs: their origin, geologic relations, and identification: U.S. Geol. Surv. Prof. Paper 366.

Streckeisen, A.L., 1967. Classification and nomenclature of igneous rocks: Neues Jahrb. Mineral. Abhandl., v. 107, p. 144-214.

Taylor, S.R., 1969. Trace element chemistry of andesites and associated calc-alkaline rocks. In McBirney, A.R. (Ed.), Proc. Andesite Conf., Oregon Dept. Geol. Min. Indus. Bull. 65, p. 43-63.

Thompson, R.N., 1973. One-atmosphere melting behaviour and nomenclature of terrestrial lavas: Contrib. Mineral. Petrol., v. 41, p. 197-204.

Thornton, C.P. and Tuttle, O.F., 1960. Chemistry of igneous rocks-[Pt.] 1, differentiation index: Am. J. Sci., v. 258, p. 664-684.

Tobi, A.C., 1963. Plagioclase determination with the aid of the extinction angles in sections normal to (010)-A critical comparison of current albite-Carlsbad charts: Am. J. Sci., v. 261 , p. $157-167$.

Uruno, K., 1963. Optical study on the ordering degree of plagioclases: Tohoku Univ. Sci. Rept., 3rd ser., v. 8, p. 171-220.

Veevers, J.J., Jones, J.G., and Talent, J.A., 1971. IndoAustralian stratigraphy and the configuration and dispersal of Gondwanaland: Nature, v. 229, p. 383-388. 
von der Borch, C.C., Sclater, J.G., et al., 1974. Initial Reports of the Deep Sea Drilling Project, Volume 22: Washington (U.S. Government Printing Office).
Watkins, N.D., Gunn, B.M., Nougier, J., and Baksi, A.K., 1974. Kerguelen: continental fragment or oceanic island?: Geol. Soc. Am. Bull., v. 85, p. 201-212. 